\title{
Russian economic policy: Challenges of growth
}

\author{
Vladimir Mau* \\ Russian Presidential Academy of National Economy and Public Administration, Moscow, Russia
}

\begin{abstract}
The paper discusses the main challenges of Russian economy at the turning period from contraction to growth. The analysis is based on comparison of global economic trends and special features of Russian performance. Among global problems, it concentrates on prospects of "non-inflation growth", perspectives of global currencies and the role of cryptocurrencies, central banks independence and their role in economic growth stimulation, new tasks and patterns of government regulation, inequality and growth. In the Russian case, the key topics are prospects of macroeconomic stimulation of growth, inflation targeting, new fiscal rule, social dynamics and new challenges to welfare state. The paper concludes that the main obstacles for economic growth in Russia are concentrated in the non-economic area.
\end{abstract}

Keywords: economic policy, structural crisis, social state, new model of growth, Russia. JEL classification: E02, E50, E60, O11.

\section{Challenges of global development}

The global crisis that started in 2008 cannot be described merely by fluctuating production rates, macroeconomic unbalance or political instability. It leads to the deep transformation that has taken over multiple aspects of life in the world's leading countries, both developed and developing ones. Over the decade-long duration of the crisis, we have seen episodes of both expansion and contraction, of both acceleration and deceleration. However, the key feature of this period is the general instability of all trends, especially economic growth and the drastic increase in uncertainty around the consequences of both technological innovations and economic policy.

Similar crises of the past, in the 1930s and 1970s, each lasted roughly ten years, although their beginning and end points are difficult to precisely determine. It seems that the current crisis is also coming to a close after a decade. The positive

\footnotetext{
* E-mail address: rector@ranepa.ru
} 
trends observed in the world economy testify to its closure, but serious risk factors could still pose obstacles to stability in the short term (Tables 1-2).

One can make five general conclusions about the current problems of the world economy.

First, in 2008-2010, experts predicted that this time developing economies (primarily China) would be the engine driving the world out of the crisis. These expectations turned out to be incorrect. Once again, the main driver was the US economy. In terms of economic growth, inflation and employment, 2017 was one of the best years of the last decade for the US. Economic growth has led to increased income and demand, thus helping clear bank balances and improve national budgets.

Second, the observed growth roughly corresponds to the moderate rates of the last fifty years (after 1965), which indicates that it has shifted to a stable trajectory. For the same reason, we can consider the discussion about "secular stagnation" to be over, at least, until new data about the trend of the next two to three years become available.

Third, the post-crisis growth does not exhibit the V-shaped "post-crisis rebound" characteristic of many past crises. This could attest to the instability of these rates. Many experts believe that by absorbing excess capacity, a rebound of this sort can create a safety cushion that softens inevitable shocks which periodically arise in the world economy (for example, see Roach, 2017). The absence of such a rebound, meanwhile, creates additional risks that could arise in the near future. This situtaion is, in our opinion, a direct consequence of successful anti-crisis policies of the last decade (see Idrisov et al., 2017, p. 14). The world learned to handle crises: lessons have been learned and, despite the exceptional severity and novelty of the problems that trouble the world, the crisis of the early twenty-first century turned out to be much milder than those of the twentieth-century. However, social stability during the crisis (i.e. successful anti-crisis policy) came at the cost of a virtual rejection of "creative destruction" (see Schumpeter, 1942; Caballero and Hammour, 1996) and a consequent negative effect on post-crisis dynamics.

Table 1

Economic growth, 2008-2017 (GDP \% change relative to previous year).

\begin{tabular}{lrrrrrrrrrr}
\hline & 2008 & 2009 & 2010 & 2011 & 2012 & 2013 & 2014 & 2015 & 2016 & $\begin{array}{l}2017 \\
\text { (est.) }\end{array}$ \\
\hline World & 3.0 & -0.1 & 5.4 & 4.3 & 3.5 & 3.5 & 3.6 & 3.4 & 3.2 & 3.7 \\
Russia & 5.2 & -7.8 & 4.5 & 5.1 & 3.7 & 1.8 & 0.7 & -2.8 & -0.2 & 1.8 \\
EU (Eurozone) & 0.4 & -4.5 & 2.1 & 1.6 & -0.9 & -0.2 & 1.3 & 2.0 & 1.8 & 2.1 \\
Great Britain & -0.6 & -4.3 & 1.9 & 1.5 & 1.3 & 1.9 & 3.1 & 2.2 & 1.8 & 1.7 \\
USA & -0.3 & -2.8 & 2.5 & 1.6 & 2.2 & 1.7 & 2.6 & 2.9 & 1.5 & 2.3 \\
Germany & 0.8 & -5.6 & 3.9 & 3.7 & 0.7 & 0.6 & 1.9 & 1.5 & 1.9 & 2.5 \\
France & 0.2 & -2.9 & 2.0 & 2.1 & 0.2 & 0.6 & 0.9 & 1.1 & 1.2 & 1.8 \\
Italy & -1.1 & -5.5 & 1.7 & 0.6 & -2.8 & -1.7 & 0.1 & 0.8 & 0.9 & 1.5 \\
Spain & 1.1 & -3.6 & 0.0 & -1.0 & -2.9 & -1.7 & 1.4 & 3.2 & 3.2 & 3.1 \\
Greece & -0.3 & -4.3 & -5.5 & -9.1 & -7.3 & -3.2 & 0.4 & -0.2 & 0.0 & 1.8 \\
China & 9.6 & 9.2 & 10.6 & 9.5 & 7.9 & 7.8 & 7.3 & 6.9 & 6.7 & 6.8 \\
India & 3.9 & 8.5 & 10.3 & 6.6 & 5.5 & 6.4 & 7.5 & 8.0 & 7.1 & 6.7 \\
Brazil & 5.1 & -0.1 & 7.5 & 4.0 & 1.9 & 3.0 & 0.5 & -3.8 & -3.6 & 1.1 \\
South Africa & 3.2 & -1.5 & 3.0 & 3.3 & 2.2 & 2.5 & 1.7 & 1.3 & 0.3 & 0.7 \\
\hline
\end{tabular}

Source: IMF data from the World Economic Outlook Database. http://www.imf.org/Publications/WEO/Issues/ 2018/01/11/world-economic-outlook-update-january-2018 


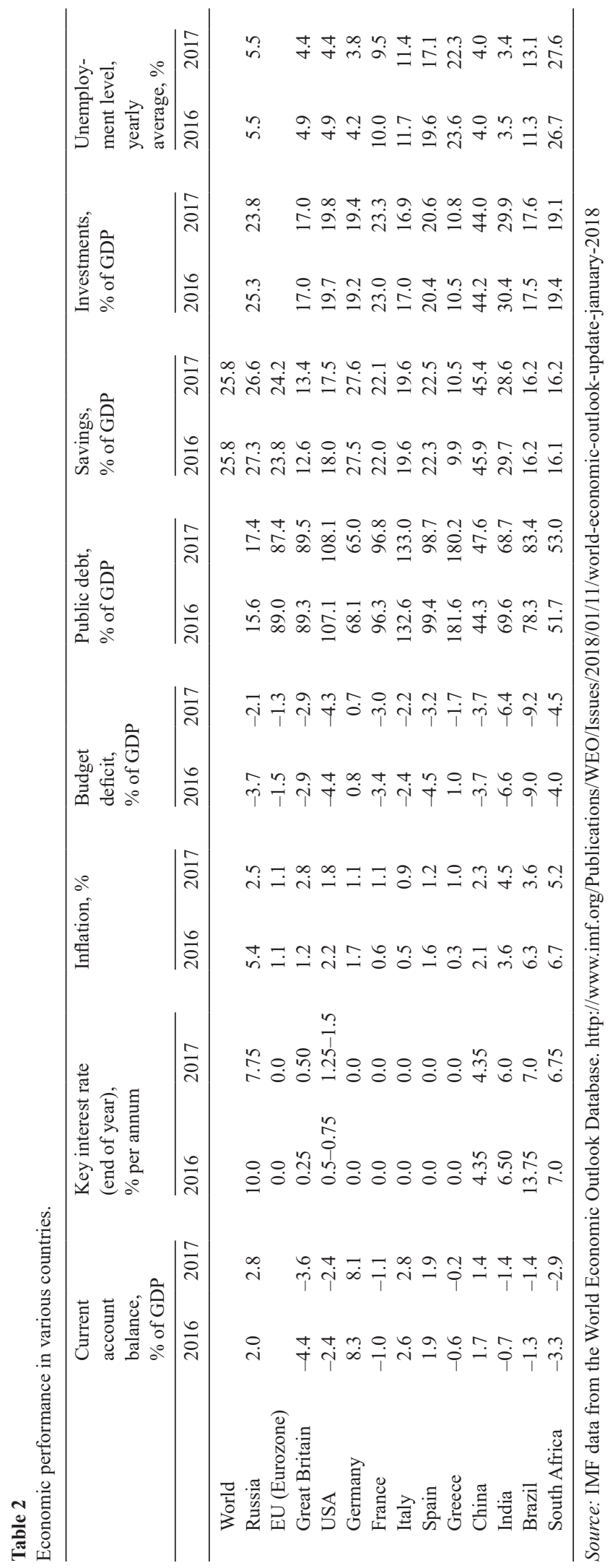


Fourth, the process of globalization continues despite gloomy forecasts made regularly over the last decade. In 2017, world trade exhibited growth rates exceeding that of GDP: $4.4 \%$ in terms of physical volume and about $10.5 \%$ in value terms, reaching a total of $\$ 17.7$ trillion (according to data from the IMF and the WTO). ${ }^{1}$ The problems and the resistance to globalization are, however, evident. World trade is growing more slowly than a decade ago, while countries are resorting to protectionist measures more often and on a greater scale. This can be explained by a few structural reasons that have long-term impact:

- countries that supply cheap goods are now focusing on domestic markets, which are significant in size both because of the high population in Asia and because of the increased affluence of the local population as a result of accelerated growth in recent decades;

- production is moving closer and closer to areas of consumption and R\&D (a trend sometimes called the reindustrialization of developed countries), which is a result of increasing labor costs in major developing countries, on the one hand, and of fundamental technological disruptions that have substantially lowered the role of the cost of labor and natural resources in the production of competitive goods, on the other hand;

- structural shifts and increasing uncertainty about the labor market in the midterm have pushed governments to limit access to domestic markets. This is also caused by increasing geopolitical tensions.

Fifth, the situation remains rather contradictory. On the one hand, global growth is accelerating and the "output gap" is narrowing, while inflation remains unusually low for this economic situation. On the other hand, the growth of productivity remains low, inequality is increasing and social problems have been exacerbated by the profound influence of technological change on the labor market.

This is the foundation for trends in socioeconomic development that will characterize at least several years to come.

Monetary policy is starting to be normalized, a fact that has not yet been reflected in increasing inflation rates. A key challenge now will be to help monetary authorities find the optimal solution to stimulate growth without allowing a surge in inflation. This task is theoretically simple but politically very complex. The tightening of monetary policy is necessary and inevitable, but it will always meet political opposition - monetary authorities will inevitably be blamed for slowed economic growth. The position of central banks is becoming all the more difficult because, in recent years, they have faced more criticism of their independence, as agencies that cannot be held responsible for economic growth and employment. Economic growth is never fully stable anyway and any slowing of it will be explained first and foremost by the policy decisions of monetary authorities.

The situation will be further intensified by the fact that, for the last four decades (since the early 1980s), inflation has been at the periphery of attention for developed countries as deflation came to be perceived as the main threat. Public opinion and policies of these countries lost their immunity to the inflation disease (whereas the political leadership and economic experts of most post-communist

\footnotetext{
1 http://www.imf.org/en/Publications/WEO/Issues/2018/01/11/world-economic-outlook-update-january-2018; https://www.wto.org/english/news_e/pres17_e/pr800_e.htm
} 
countries did not). Meanwhile, slowing monetary normalization could lead to a surge of high inflation, however strange that may sound at present.

The normalization of monetary policy carries with it another risk related to the dramatic increase in the importance of financial markets, including the real sector's dependence on them. Indeed, according to data from the Bank for International Settlements, the cumulative assets of the Federal Reserve System, the European Central Bank and the Bank of Japan grew by $\$ 10.4$ trillion, while the growth of the nominal GDP in those countries was only $\$ 4.9$ trillion. Thus the difference of $\$ 5.5$ trillion represents the liquidity that makes it possible to appreciate the "financial bubble" of global assets. ${ }^{2}$ The deflation of this "bubble" (whether spontaneous or as a result of the central banks' contracted balances) could cause serious shake-ups not only in individual companies but also in national economies oriented toward overvalued financial assets.

Fiscal policies of developed countries will be important issues. Sectors of human capital and infrastructures are undoubtedly budget priorities; in recent years, this fact has been reflected in election campaigns in every developed country. This, however, gives rise to a conflict between the need to increase budget expenditures and the possibility of funding them. There are only three ways out of this conflict: increasing taxes, redistributing resources from other sectors and increasing government debt. Raising taxes is fraught with the risk of inhibiting growth. The redistribution of spending to benefit high-priority sectors is politically limited by the demands of the defense sectors. A factor in favor of increasing debt is the unprecedentedly low interest rates (i.e. debt is cheap), but the high level of public debt in leading countries and the risk of a full-scale budget crisis as a result of normalized monetary policy and growing interest rates make strong arguments against it.

There is an ongoing discussion about the relationship between monetary and budgetary methods. The former risks missing the onset of an inflation surge. The latter is fraught with a lengthy budgetary crisis for the foreseeable future.

A highly important problem combining both macroeconomic and structural challenges is developing a new model for the welfare state that corresponds to contemporary technological, demographic and social realities. The crisis of traditional systems of state pensions, health care, education and labor market regulations (those that were formed by the twentieth-century industrial model) is becoming more and more evident. So far, it has not been possible to strike a balance for efficiency, reliability and financial sustainability. The private models of recent decades have also been unable to provide an adequate solution to this threepronged problem. Social programs and services are becoming more expensive, which leads to either (a) the displacement of financing for other programs (infrastructural ones, for instance), (b) increased taxes or (c) decreased revenue in these sectors. This gives rise to a conflict between economics and politics: all these options of financing are unacceptable solutions when it comes to steady growth, but these sectors of human capital are presently the key priorities of state policy for ensuring this growth. The quality of education and health care is a focus of election campaigns in all developed countries and will remain so for the fore-

\footnotetext{
2 http://fingfx.thomsonreuters.com/gfx/rngs/GLOBAL-CENTRALBANKS/010041ZQ4B7/index.html; http:// www.imf.org/external/pubs/ft/weo/2017/02/weodata/download.aspx
} 
seeable future. Moreover, the solution to these problems cannot be reduced to purely fiscal means: the problem is not a matter of money, but a matter of reforming the very principles of how these sectors function. In other words, reforming the welfare state requires coordinated actions in the structural, fiscal and financial spheres, to say nothing of the political consensus (or political will) needed for these reforms.

Globalization also poses new challenges for the welfare state. In 2016-2017, economists came to accept the thesis about the conflict between the economic and sociopolitical consequences of globalization. From an economic perspective, free trade leads to growth in overall prosperity and, in this regard, the findings of classical economics of the eighteenth and nineteenth centuries have been confirmed by the course of history, including in recent decades. Political consequences have, however, been ambivalent, leading at certain stages to growing inequality and consequent social conflicts.

The belief that globalization benefits everyone by guaranteeing growth has been replaced by the understanding that this benefit comes only in the final analysis and applies only to certain people and certain spheres of activity. Globalization has winners and losers, hence the spreading of populism, especially in developed countries. However, this does not mean that a rejection of globalization will bring political stability (reduced conflict) or normalization (a decline in populism). To the contrary, globalization is important as a source of additional growth, which is especially important in the recession conditions of the last few years (or the last few decades, when speaking of Japan). At the new stage, when the welfare state is being restructured, it is crucial to also develop means of compensating those who have suffered substantial losses from globalization. ${ }^{3}$ Of course, this conclusion should be met with caution: compensation should not disincentivize the efforts of people and companies to adapt to the new realities.

The modernization of the welfare state has a direct effect on the chances of increasing productivity. To a significant degree, its stagnation reflects the state of human capital: professional skills and qualifications lag behind rapid technological changes that are radically transforming demand for labor resources. There are obvious structural imbalances on the labor market: the demand for qualifications does not match the supply. Governments can alleviate this problem in two ways, which are not necessarily mutually exclusive alternatives: they can actively invest in education (retraining personnel) and intensify the redistribution of resources from the more successful to the "victims" of globalization and technological progress. The first path is preferable, but more difficult to enact. The second creates risks of exacerbating a welfare mentality. Though it would alleviate acute social problems, it does not offer long-term solutions.

Finally, 2017 demonstrated how leading countries are adapting to the new realities. A wave of populism struck in 2016, most vividly with the Brexit referendum in the UK and the presidential elections in the US. It, however, did not have a negative effect on economic trends, whether national or global. Despite po-

\footnotetext{
3 "Other means of alleviating the contradictions between globalization and prosperity are the emigration of workers or introducing protectionist measures in trade. But these options are characteristic for earlier phases of industrialization, that is, before the appearance of the modern socialist state. Furthermore, the lesser successes of populism in Europe (compared to the US) are related to the EU's more developed systems of the welfare state that compensate for the losses from globalization." (Rodrik, 2017).
} 
litical complications, economic trends were positive in terms of both growth rates and the state of financial markets. In addition, the populist trends in developed countries did not develop steadily: they certainly manifested in the election results in several European countries but did not decide those votes. Populism apparently will remain a substantial factor influencing political and economic processes for the foreseeable future, especially in developed countries. This will particularly be encouraged by the current high level of inequality. ${ }^{4}$

Now we can begin to take stock of the global structural crisis that began in 2008. It poses several fundamental questions, the answers to which were completely unclear at the beginning. Determining them has taken a rather long period: "a turbulent decade." Now we have a clearer understanding of the contours of the future post-crisis world. Against this background, a new intellectual agenda is taking shape, through pointed discussions about the key problems of socioeconomic development in both the world as a whole and in individual countries. We are essentially gaining an understanding of the contours of the "new reality" that we must function in for the duration of the foreseeable period ahead. ${ }^{6}$

First. The geopolitical situation has shifted toward a multipolar, multivector world, unlike the bipolar model that took hold after the crisis of the 1930s and the unipolar one that followed the crisis of the 1970s. The coming period will be characterized by a system of complex, diverse and highly dynamic configurations of various alliances and groupings. In the economic sphere, this trend is apparent primarily in the transition of world trade from a unified system based on the principles of the WTO, towards the predominance of variable, multispeed trade agreements.

Second. New concepts about the model of economic growth are taking shape. The situation can no longer be described in terms of "secular stagnation," since economic growth is gaining momentum. However, this model substantially differs from the previous ones described in detail by mainstream economics. We must re-conceive the relationship between the basic concepts of macroeconomic theory: growth, employment, inflation. The new mystery is inflation-free growth and science still needs to explain this phenomenon. ${ }^{7}$ Structural and technological changes may lie at its base; these can lead to a substantial decrease in the cost of new products and services, which, in all likelihood, will negatively affect the nominal rates of economic growth. Recently, a new term to describe this phenomenon has been coined: "technological deflation." It may not be very precise, but it fully reflects the essence of the phenomenon. There are also more simple explanations for it: the appearance of longer time lags between changes in monetary policy and inflation expectations.

\footnotetext{
4 According to the data of the World Inequality Report 2018, the share of national income, belonging to the wealthiest $1 \%$ of the US population, grew from $11 \%$ in 1980 to $20 \%$ in 2014 , while the poorest $50 \%$ only have $13 \%$ of income. The share of the wealthiest $1 \%$ for approximately the same period grew from $4 \%$ to $20 \%$ in Russia, $6 \%$ to $14 \%$ in China and $6 \%$ to $22 \%$ in India (World Inequality Lab, 2018).

5 The issues and challenges posed by the global structural crises are examined in further detail in our book (Mau, 2016, pp. 27-29, 342-347). They are common to all crises of this sort. But the solutions to them, of course, are specific for each crisis.

6 Earlier one could say "over the course of several decades," but now the radical acceleration of technological and socioeconomic processes makes it impossible to define the temporal horizons of the new model.

7 "Since the summer of 2016, the global economy has been in a period of moderate expansion, but inflation has yet to pick up in the advanced economies. The question is why." (Roubini, 2017).
} 
Third. The independent status of the central banks is being questioned. After stagflation of the 1970s and the difficult struggle against inflation in developing countries and then in post-communist ones, the independence of monetary authorities was considered an unwavering principle that made it possible to escape the inflation legacy of the better part of the twentieth century. The last significant step in this direction was the Blair government's 1997 decision to formally separate the Bank of England from the Treasury (though it had already been independent de facto for a long time). The corresponding provisions were introduced to the Constitution of the Russian Federation of 1993. The discussion sharpened considerably when the crisis began in 2008: central banks played a prominent role in preventing an economic catastrophe, demonstrating a power not subject to democratic procedures and going far beyond the reach of constitutional governments.

At present, political efforts are being made to limit the independence of central banks while imputing them with the responsibility to ensure not only the stability of the monetary system but also economic growth. Statements of this sort have been heard in both legislative and executive branches of power of several countries, including the US.

However, these issues are technically legal in nature rather than economic. In conditions of global crisis, central banks have repeatedly taken critically important actions to prevent recessions and stimulate economic growth and the basic principles of monetary policy and key solutions to bail out (or refuse to do it) institutions of the financial market have been made in unity with legislative and executive branches of power, regardless of the independent status of the regulator. However, formal introduction of the responsibility for securing economic growth to the mandate of central banks will become a significant factor in limiting their independence.

The position of money emission centers in the system of public authorities (their independence) should not be viewed abstractly, outside the historical context and remain the only possible one forever. This question cannot be answered in a dogmatic manner. The role of central banks can change over time. It still remains unclear whether the time has truly come to change the established model of central banks and what their place will be in future economic configurations. ${ }^{8}$

A new problem in the activity of central banks is their relation to currency emission. This problem takes two forms. On the one hand, the appearance of new supra-national currencies denies national central banks' their right of emission: that was precisely what happened in the Eurozone. On the other hand, the appearance of cryptocurrencies poses new challenges, the volume and character of which are still difficult to grasp. However, in the extreme version, in the case of a full-fledged legalization of cryptocurrency in some country, central banks could find themselves in competition with public and private monetary systems.

Correspondingly, the fourth intellectual and political challenge of post-crisis development is the change in currency configurations. Global crises of the past

\footnotetext{
8 Dani Rodrik sees the calls to reject the independence of central banks as a dangerous form of political populism. At the same time, he develops an argument about the need to move their mandate beyond the guarantee of monetary stability. "Independent central banks played a critical role in bringing inflation down in the 1980s and 1990s. But in the current low-inflation environment, their exclusive focus on price stability imparts a deflationary bias to economic policy and is in tension with employment generation and growth.” (Rodrik, 2018).
} 
have led to substantial transformations, to the appearance of new reserve currencies. Studies, conducted in 2008-2010 on the influence of the structural crisis on currency systems, addressed the future of the yuan, artificial currency units (such as SDRs) or the growing role of regional reserve currencies. ${ }^{9}$

Over the course of the decade, the direction of discussion radically changed: cryptocurrencies and the technologies related to them took a central position. In 2017 , cryptocurrencies were an object of booming demand, multifold appreciation and rapid depreciation. They were also the topic of intense discussions among economists and politicians and posed fundamentally new questions for legal science for decades to come. Both the basic possibility of using cryptocurrencies in legal monetary circulation and the expediency and possibility of public regulation of them are being discussed. The risks that cryptocurrencies will be used to evade taxes and carry out illegal transactions are objects of particular attention. ${ }^{10}$

After the initial period of interest in the new technology and the opportunities for its broad use came natural doubts about its future. Around the beginning of 2018, criticism of this tool (and of all blockchain technologies) came from business and expert communities (Stinchcombe, 2017). The attitude of governments and monetary regulators toward cryptocurrencies, however, radically differs from country to country: from a willingness to accept them as an independent unit of payment to suggestions to outlaw them as sources of growing risk (both macroeconomic and sociopolitical). ${ }^{11}$

Presumably, cryptocurrencies will not become a key means of payment, let alone international money, in the coming years. Nevertheless, this phenomenon deserves close attention because of its socioeconomic, judicial, moral and ethical consequences.

In the meantime, we can express a few preliminary ideas on the topic. First of all, the ideas of mid-twentieth-century right-liberal economists about the preference of private currencies over state ones are being realized in cryptocurrency. As often happens in history, the trend was predicted correctly, but the form in which it has taken place turned out to be qualitatively different from what was expected. Secondly, it remains an open question whether cryptocurrencies can take on all functions of money or if their role is limited to a means of payment and exchange. Thirdly, specific forms of cryptocurrency are not perfect tools: for the time being the technology standing behind it (blockchain) is more important and, if the demand for these technologies and tools is sustained in the mid-term perspective, then new, much more effective forms of cryptocurrency will emerge.

\footnotetext{
9 The yuan's potential as a reserve currency was an object of increased attention of researchers after the onset of the global crisis in 2008. For example, see Murphy and Yuan (2009), Frankel (2012), Prasad (2016).

${ }^{10}$ The analysis of the problems of blockchain and cryptocurrencies is presented in: IMF, 2017. It is noted here that cryptocurrencies have already been used to avoid the standards of currency control in China, Venezuela and Cyprus. These problems explain the decision to ban ICOs in China.

11 The authors of the "Monitoring of Russia's economic outlook" offer an interesting economic-political observation regarding how the authorities of various countries treat cryptocurrencies: "In the final weeks of 2017, cryptocurrencies - which in a certain sense are an unreal sector of the world economy - were awarded a mutually exclusive status. On the one hand, representatives of the Bundesbank virtually rejected the possibility of the legal use of cryptocurrencies in the Eurozone. On the other hand, the head of Belarus, and somewhat earlier the head of Venezuela, announced the broad legalization of them. That is to say, effectively working markets mostly fear cryptocurrencies, while ineffective and destroyed markets are presenting them as a tool of financial healing, as a product of another economic civilization." (RANEPA and Gaidar Institute, 2017).
} 
Thus, the first cryptocurrencies are merely a prototype for the future. On their own, they cannot become a reserve currency or international money, but their role will grow rapidly. Even now, we must discuss their future relationships with the state and find ways of minimizing the risks associated with them (their use in tax evasion, criminal transactions etc.)

Fifth. The global crisis poses new demands to state regulation, including in the economic sphere. The crisis of the 1920s led to the formation of "big government" based on the Keynesian model. The crisis of the 1970s resulted in a policy of liberalization and deregulation. The current global crisis has posed the question about the need for new regulation - the necessity of supplementing the global market with equally global rules of the game. The G20 was assigned to the role of this regulator, but we cannot yet confirm whether it has operated. It cannot be excluded that this function will gradually be taken on by the relationship between the US and China, though it is unlikely that it will be any officially recognized mechanism. Systems of regulation, working de facto and reflecting real correlations of power, often turn out to be more effective than formally confirmed and approved ones. ${ }^{12}$

Systems of national regulation are facing even more complex problems. Contemporary technologies lead to a decrease in the role of expenditure on labor and natural resources in the functioning of the newest sectors and productions. ${ }^{13}$ Quality (predictability, reliability) of public management is becoming the determinant for businesses making decisions about investment - both for the largest companies as well as for small ones. Thus, states are beginning to compete for investors, not with the cost of labor or natural resources, but with the quality of public management.

In parallel, we can observe one more process in the transformation of the state model - a significant portion of functions is leaving the domain of the state apparatus and moving to specially developed platforms. The thesis of the "state as a platform" was widely circulated in 2017. If cryptocurrency is the realization of the predictions of right-wing economists, then the implementation of platform solutions essentially means the realization of old socialist ideas about the "withering away of the state." 14

Sixth. The problem of inequality will remain one of the key issues of political and expert discussions for the foreseeable future. Economic, social and political challenges are all concentrated in it. The discussion requires a more precise definition of observed trends, as well as an analysis of the relationship between inequality and economic growth. To what degree is the growth of inequality a consequence of the contemporary model of economic growth? Is the growth of inequality a factor inhibiting economic growth or is it neutral in relation to it? Recently, two fundamentally different answers to these questions have been taking shape in the economic discourse. Some economists insist that inequality will destabilize growth and even lead to a recession, while others believe inequality is the price that must be paid for economic growth. In practical terms, the key issue

\footnotetext{
12 Zbigniew Brzezinski spoke of the possibility of forming a G2 instead of a G7 a decade ago.

13 This process lies at the foundation of the so-called reindustrialization of developed countries.

14 The corresponding declaration was formulated at the twenty-first congress of the Communist Party of the Soviet Union, which adopted the Party's Third Program.
} 
is working out the course that ensures the growth of well-being for all members of society regardless of inequality statistics (inclusive growth).

Thus, we can say that the global structural crisis is coming to an end, although several important questions regarding the post-crisis world order still remain unanswered.

\section{Russia's socioeconomic policy}

Russia entered the global crisis at the same time as other leading developed and developing countries, but now we can speak of a certain lag of its development in our country. The considerable reserves accumulated by 2008 and the macroeconomic stability (low debt and surlpus budget) helped alleviate the sociopolitical consequences of the crisis and it was mostly exacerbated in 2014-2015. The successful anti-crisis policy of 2015-2016 minimized the decline, exerted control over basic macroeconomic parameters, maintained reserves and suppressed inflation to an extent that had not been seen in a quarter of a century.

In 2017, Russia's economic performance showed positive trends, but was unstable and contradictory in many parameters (Table 3).

Resumption of GDP growth. In 2017, GDP growth reached 1.5\%, which approximately corresponds to potential growth, estimated at $1.5 \%$ to $1.8 \%$ for the contemporary Russian economy. ${ }^{15}$ In the context of accelerating growth of the global economy and leading developed and developing countries, this rate seems low. It does not correspond to the "political target" - to grow at a rate faster than the world average. ${ }^{16}$

As we noted above, the current crisis is characterized by the lack of a V-shaped rebound. Taking into account that the crisis in Russia has lagged, then we can expect higher growth rates if external economic conditions are favorable and at least some structural and institutional reforms are put forward. After all, the postcrisis recovery of the countries in the Eurozone - the main economic partner of Russia - happened slowly over the last few years, which brought up the question of secular stagnation.

For all the importance of growth, there remains the risk of populism aimed at stimulating it, which would only repeat the sad results of the "acceleration" policy of 1986-1989 in the USSR, when nominal growth rates were accompanied by a radical unbalancing of the Soviet economy that led to its collapse. ${ }^{17}$

The anti-inflation policy of the Bank of Russia has achieved irrefutable success. In 2014, the announcement of a 4\% target for inflation by the end of 2017 was seen as propaganda at best. This goal was, however, consistently pursued and the growth rate for consumer prices of December 2017 relative to December 2016 was only $2.5 \%$. This low level of inflation, unprecedented for post-communist Russia, has created new opportunities for investment activity. This result was achieved thanks to the uncompromising anti-inflation position of the Central Bank management (tight monetary policy), supported by the president and the government's pursuit of cutting budgetary spending. Due to the external

\footnotetext{
${ }^{15}$ For further detail, see Sinelnikov-Murylev et al. (2014).

${ }^{16}$ Presidential address, Dec. 1, 2016. https://www.wto.org/english/news_e/pres17_e/pr800_e.htm

${ }^{17}$ For more on the policy of "acceleration," see Mau (2014).
} 


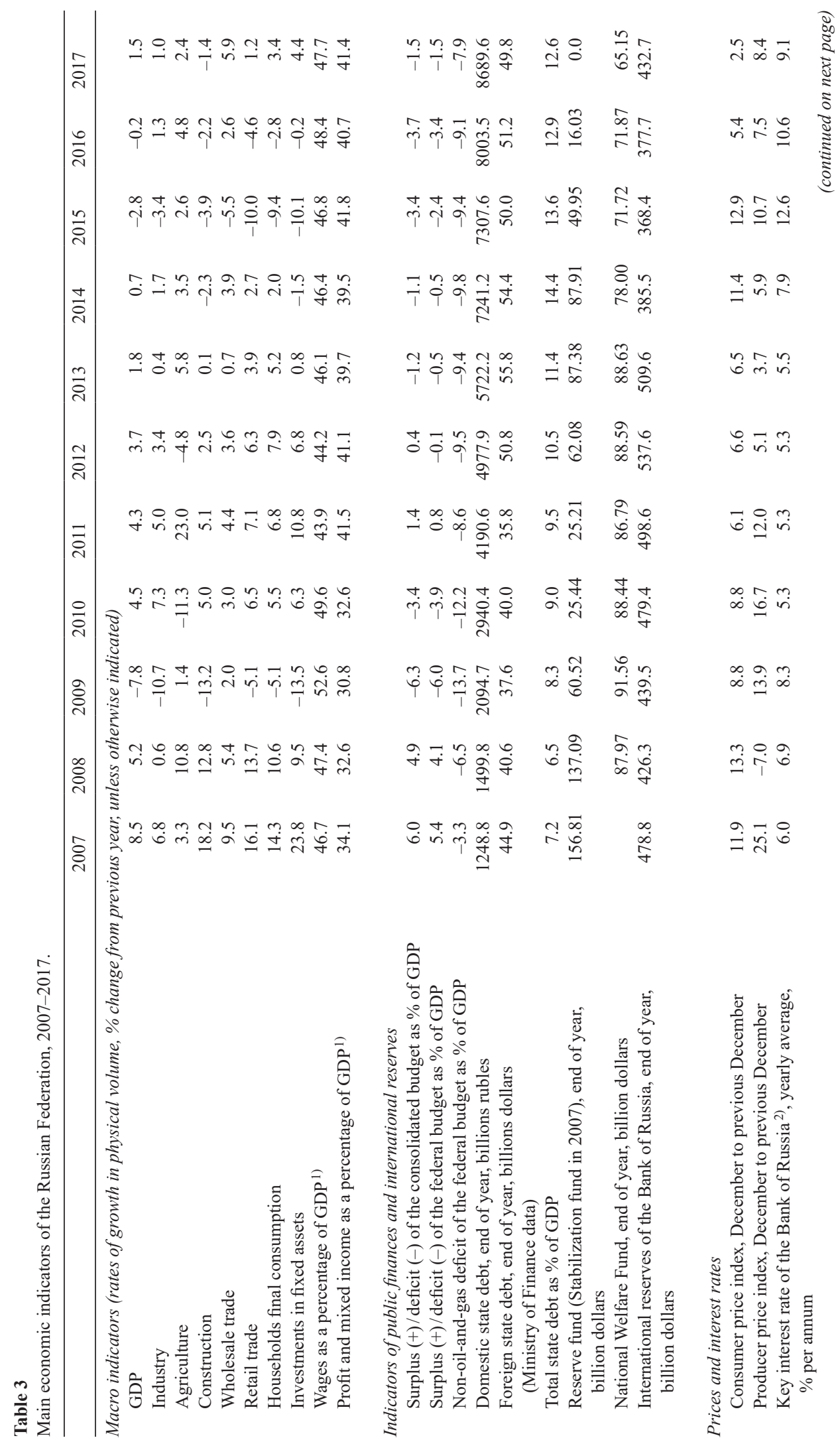




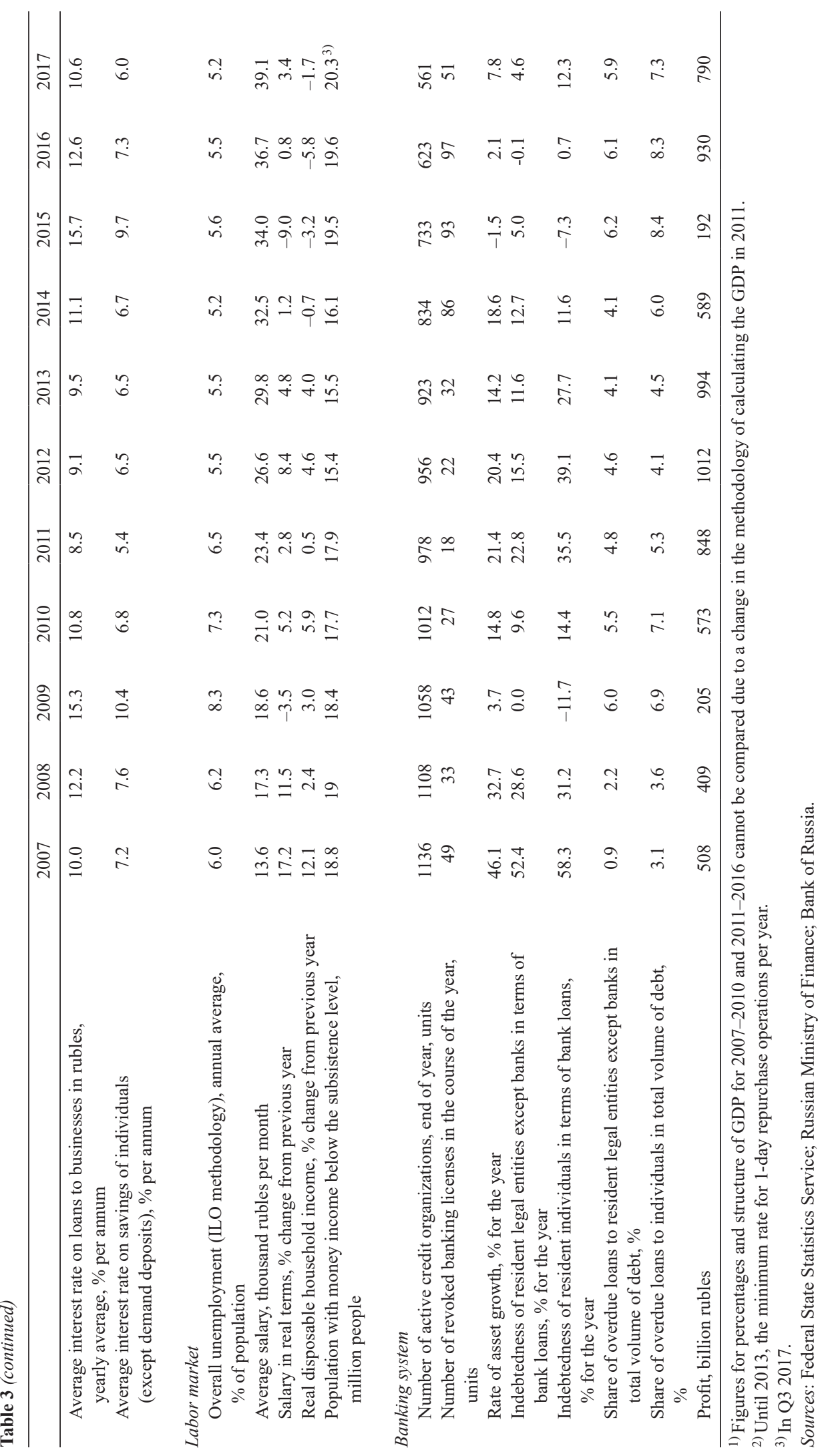


shocks that Russia encountered in 2014-2015, this was the only possible set of actions, though they were very complicated politically. At the beginning of 2018, real interest rates in Russia, however, remained one of the highest in the world, exceeding $5 \%$.

Low inflation strengthens the growing trust in the ruble. In 2017, as savings increased overall, the amount of assets in foreign currency decreased in accounts held both by individuals (from $23.1 \%$ to $19.9 \%$ ) and by organizations (from $36 \%$ to $34.7 \%$ ).

The success of the anti-inflation policy has had another result that might be called an intellectual one. We can now say that we have exhausted the discussion about the "unmonetary nature" of Russian inflation that has been going on since the beginning of post-communist reforms, i.e. over the last quarter of a century. The low growth rate of consumer prices has not yet allowed us to decisively lower the interest rate, which can be explained by the inflation expectations of around $8 \%$ (twice as high as the target). This phenomenon is not unique: it reflects the long period of high inflation and the Russian population's psychological adaptation to it. Meanwhile high inflation expectations poorly correspond to the recent trend in savings' behavior to de-dollarize mid-term deposits. At present, the share of ruble deposits is about 80\%. Moreover, in 2016-2017, midterm dollar deposits decreased from $25 \%$ to $9 \%$ and a similar trend has been demonstrated by long-term deposits.

Of course, low inflation is a necessary factor for investment activity, yet an insufficient one, insofar as external economic factors play a significant role here. This is a problem that must be addressed by actual institutional reforms.

We can observe a weakening of the dependence of the ruble's exchange rate on fluctuating oil prices, which for a long time was its most important feature (Fig. 1). To put it more precisely, the increase in oil prices in 2017 had a weaker effect on the ruble's exchange rate than the preceding fall of oil prices. As a result, the end-of-year oil price in rubles matched the record numbers of early 2014 (3800 rubles per barrel), which guaranteed additional revenue both for exporters and for the Russian budget. This does not mean the link between these two factors was fully destroyed: oil and gas remain the most important articles of Russian ex-

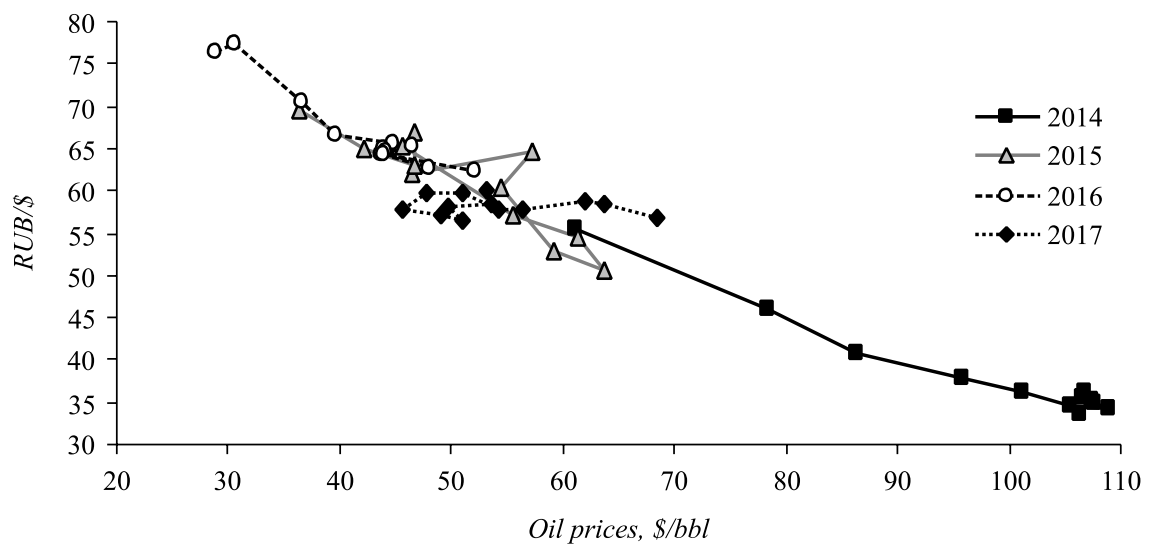

Fig. 1. Correlation of oil prices and the ruble's exchange rate, 2014-2017. 
port and the budget and the ruble's value will undoubtedly react to a substantial increase (or decrease) of prices.

Under these conditions, it is fully natural that the reserves of the Central Bank for 2017 substantially grew from $\$ 377.7$ to $\$ 432.7$ billion.

Discussions of budgetary policy were dominated by questions of maintaining the deficit at an acceptable (controllable) level, lowering the debt burden of Russia's regions and developing measures to increase the efficacy of budgetary spending. It is no less important that this was the first year after the introduction of a new fiscal rule that limits the budgetary use of revenues from oil and gas export at prices of $\$ 40 /$ barrel.

In 2017, tight budgetary policy restricting domestic demand was consistently implemented: in conditions of slow recovery of economic growth, the deficit of the consolidated budget was $1.5 \%$ of GDP. According to estimates of the Russian Ministry of Economic Development, in 2018 there may be a federal budget surplus.

Broader recognition has been given to proposals for a budget maneuver increasing financing of so-called productive sectors, namely those involving human capital (education, healthcare) and infrastructure. However, the key question here is what the source of funds will be. ${ }^{18}$ In theory there can be four.

First, a tax increase that directs additional revenue toward priority sectors. Most members of the expert community find this option politically unacceptable.

Second, a redistribution of funds from certain sectors (non-productive) to others (productive). This redistribution can be either in absolute (cutting from some and transferring the balance to others) or in relative terms (directing additional budgetary revenue from economic growth toward priority sectors). Clearly, the second option is politically preferable and more realistic.

Third, an increase of the budgetary deficit and a corresponding increase in loans on the financial market. This option would contradict the course towards budgetary consolidation and would be fraught with macroeconomic destabilization.

Fourth, a change in the fiscal rule increasing the "cut-off price" to $\$ 45 /$ barrel. This option was supported by the Center of Strategic Reforms as the most acceptable one and the most likely to bring a rapid increase of investment in priority sectors. The Ministry of Finance of the Russian Federation spoke against it and was supported by several experts who emphasized that changing the fiscal rule just a year after it took effect would discredit a highly important instrument of economic policy in contemporary Russia.

The solution to the issue of the budget maneuver should come out of a discussion of the corresponding sectors' ability to effectively use the additional resources that they would receive.

Macroeconomic stimulation of growth. The low growth rates pose a question of the chances for stimulating growth using methods of budgetary and monetary policy. Discussions on this topic are at the center of attention for Western economists, many of whom insist on the expediency of maintaining powerful budgetary stimuli, especially in the case of curtailing a very soft monetary policy. These problems have been discussed in Russia for several years now.

In 2017, insistent appeals were made in favor of an energetic budgetary and monetary stimulus: aggressively lowering interest rates of the Central Bank and

${ }^{18}$ For more detail, see Idrisov et al. (2015), Kadochnikov et al. (2016). 
simultaneously expanding budgetary injections into the economy, even more so because the low public debt allows increased borrowing. The points made by opponents of these measures were also fairly clear: in Russia the economy is inflationary, not deflationary and, in this situation, monetary stimulation would lead not to investments but rather to a flight from money, i.e. increased inflation and higher interest rates. Budgetary stimuli are also limited: both the relatively low efficacy of budgetary spending and the lack of labor and production reserves, which could take effect if public investments were made. Conservative macroeconomic policy is seen here as a prerequisite for renewing stable growth.

The experience of recent crisis years shows that measures of monetary and budgetary policy do not automatically lead to renewed growth. They can help prevent a more severe crisis but are not nearly enough to drive stagnant economies toward growth.

Evaluating the opportunities for stimulating growth in Russia through budgetary and monetary policy, we must keep in mind the following three conditions. First, the key issue of monetary policy remains inflation, not deflation. Therefore, secondly, for both macroeconomic and institutional reasons, real interest rates remain rather high, which is an obstacle to investments. Thirdly, the external political situation is obviously worsening as sanction pressures intensify and this factor cannot be compensated by macroeconomic stimulus measures.

These conditions substantially limit the possibility of stimulating growth on the supply side (and especially by budgetary means). External shocks always demand budgetary consolidation, not mitigation. Furthermore, sanctions limit the possibility of global supply responding to a possible increase in Russian demand. Supply factors, especially on the side of Russian companies, are priorities for ensuring the stable performance of the domestic economy.

In such conditions, budgetary stimulus is likely to become an additional factor of inflation and thus will only limit opportunities for decreasing interest rates and increasing the availability of credit. Maintaining high interest rates today is the biggest obstacle to the availability of credit, i.e. for increasing the supply of goods and services. Additionally, unlike in most developed countries, continuing the course towards lowering inflation and increasing the availability of credit is the key macroeconomic task for stimulating growth in Russia.

Incidentally, the problem of growth, as the experience of developed countries shows, in principle cannot be resolved exclusively by macroeconomic manipulations. Fiscal and monetary policies must be appropriate to specific circumstances of the given country, but they can only create the conditions for growth or undermine perspectives for it. For stable economic growth leading to increased quality of life for the society, a multipart complex of institutional and structural measures must be implemented.

Investment activity of business is the most important factor for stable economic growth. Investments in fixed capital grew by $4.4 \%$ and, for the first time since 2013, they demonstrated a positive trend.

The situation here remained ambiguous. Mortgage loans demonstrate high growth rates. In 2017, the total mortgages issued exceeded 2 trillion rubles, which is $37 \%$ higher than the figures for 2016 . At the end of 2017, interest rates on ruble mortgages went below $10 \%$ annually for the first time in history, which is an important indicator of a recovering economic and social situation. Investments 
in fixed capital began to grow, but this primarily pertains to state investments in buildings and infrastructure, as well as investments in the oil and gas sector. At the same time, construction has decreased, which, strictly speaking, contradicts the other observed parameters.

The government and the expert community have begun to discuss mechanisms for attracting additional investment resources from private business. This pertains to expanding institutions of private-public partnership and to the opportunities for implementing a new instrument: infrastructural mortgages.

The banking sector grew at rapid rates: assets increased by almost $8 \%$, which occurred despite sanctions that were largely directed against the financial sector. At the same time, the number of credit organizations continued to decrease: from 623 to 561 over the course of the year and there were 51 cases of licenses being revoked (as opposed to 97 in 2016). For the most part, these were minor banks whose total assets make up less than $1 \%$ of the aggregate assets of the banking system.

Qualitative parameters were not, however, the most significant aspect of the banking sector's performance. In 2017, the Central Bank introduced a new bailout mechanism that was used for major private banks: FK Otkrytie, Binbank and Promsvyazbank, which were transferred to the direct control of the regulator. This posed a fundamental question about the future of the banking system in Russia. A massive bailout of the banking sector strengthened the position of state banks. Major private banks (including Otkrytie and Binbank) themselves took part in the bailouts, actions which made it possible for the private banking sector to grow. The new bailout model signified a decisive step towards nationalization. It is true that the Central Bank has declared its intentions to transfer the two banks it bailed out to private hands, but the chances and results of such a transfer look uncertain. Promsvyazbank, apparently, will remain public and is being transformed into a bank serving state defense interests.

Ensuring the growth of population well-being is the most important challenge of a country that has undergone an acute crisis. It is all the more important in a situation where economic growth has ceased to be an unambiguous synonym for improved welfare: contemporary technological innovations are capable of maintaining GDP growth on their own while simultaneously increasing the quality of life. ${ }^{19}$ The recession of 2015-2016 had the most negative impact on the quality of life, leading to a significant growth in the poverty level and to a decrease in consumption levels. In this regard, economic performance in 2017 is paradoxical.

Real wages have begun to increase (by 2.5\% in Q1 to Q3 of 2017, 3.4\% for the year), which is manifested in relation of their share to business profitability (Fig. 2). However, real incomes continued to decrease (1.2\% for Q1 to Q3 of $2017,1.7 \%$ for the year). At the same time, retail began to grow (a growth of $1 \%$ for the year) and household consumption grew at an even more rapid rate (3.5\%). From January to September of 2017, the poverty rate was $13.8 \%$, which corresponds to the level of the similar period of 2015-2016, but was higher than the level observed in 2012-2014.

There are various explanations for such divergences: the increase in household consumption, the growth of consumer credit (bank loans to the population increased

${ }^{19}$ For more detail, see Idrisov et al. (2017, pp. 15-16). 


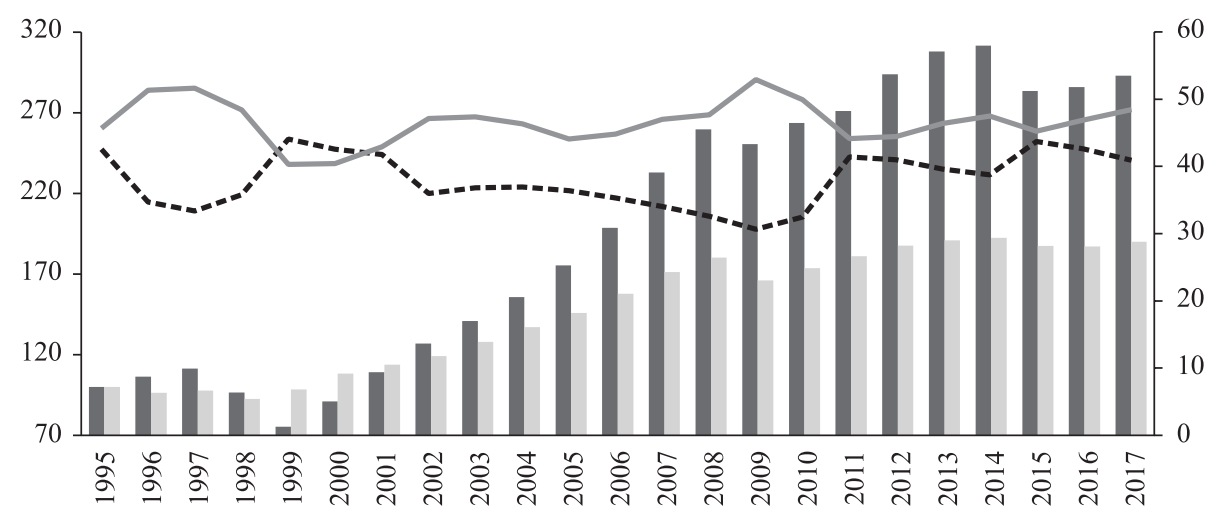

\begin{tabular}{ll|} 
Wages index $(1995=100)$ & GDP index $(1995=100)$ \\
Wage share in GDP & $\ldots-\ldots$ Profit share in GDP \\
\hline
\end{tabular}

Fig. 2. Gross profit and wages as a percentage of GDP (right scale).

Source: Federal State Statistics Service.

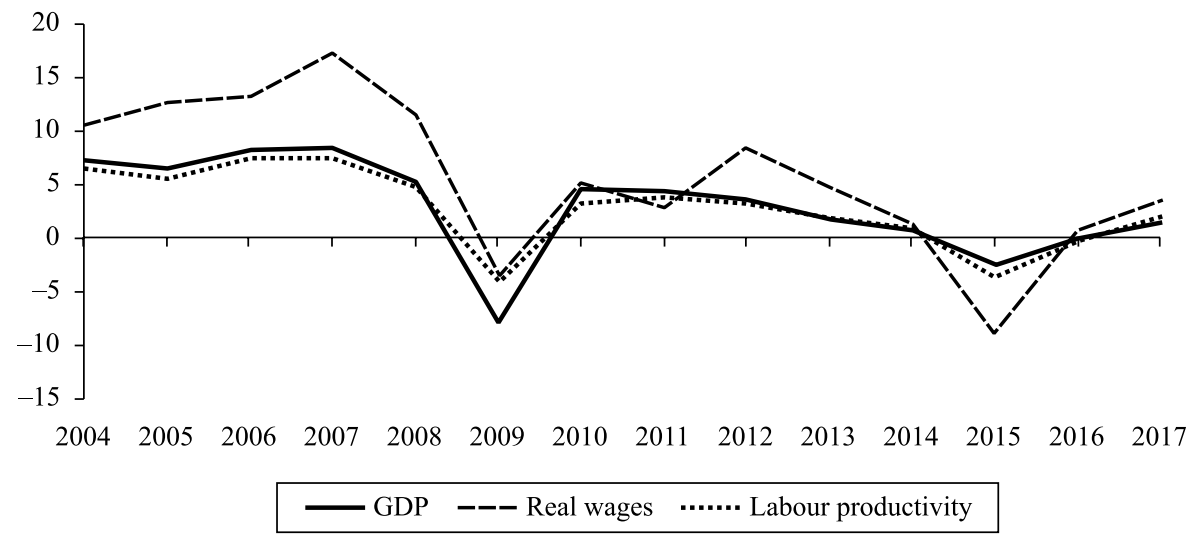

Fig. 3. Growth rates of real GDP, real wages, and labor productivity.

Source: Federal State Statistics Service.

by $9.5 \%$ ), the growth of online purchases. Overall, we can speak of the gradual retreat of households from the savings' model of consumption and an intensifying tendency toward consumption. At this stage, these behavioral shifts can positively affect the country's economic development by activating market demand.

At the same time, wages began once again to diverge from GDP and productivity. This trend, acceptable for the recovery stage of growth, can be dangerous if it becomes a constant element of the growth model (Fig. 3).

\section{Conclusions regarding further development}

Russia faces a difficult period of consolidating growth and reaching its desired parameters for economic and social performance. The key challenge for the coming period is attaining economic growth at rates exceeding the world average and ensuring a stable increase in the quality of life. 
The Russian economy, at least since the end of the transitional period of the 1990s, has demonstrated a connection to global trends and challenges. Thus the restoration of a stable and global economic growth creates the foundation for a positive outlook in Russia. Of course, several important institutional decisions must be made to support domestic growth and they are well known from economic discussions of recent years. ${ }^{20}$

We would like to draw attention to several possible priorities and risks of forming a contemporary model for economic development. For stable economic growth, undoubtedly, one needs a strategy. However, in the conditions of contemporary technological trends, any strategy becomes obsolete the very moment it is approved. The role of the strategy is to see alternatives and set priorities without settling into dogma and tying the government's hands. The long-term strategies that were developed in our country in the past were never fully executed. It would, however, be superficial and erroneous to reduce an explanation of this phenomenon to the low quality of corresponding documents or ineffective executors.

In contemporary conditions, when technology - and with it, our way of life - change not from generation to generation but several times over the course of a single generation, carrying out an approved strategy is the same as preserving a lag. For instance, in 2011, when Strategy-2020 was developed (see Mau and Kuzminov, 2013), concepts such as cryptocurrency or blockchain did not exist in the minds of political and expert communities, but now the perspectives for models for public management and monetary systems cannot be seriously discussed without them. At that time, the perspective of shale gas and tight oil were unclear and few knew about 3D printing. Today, the mastering of these technologies has not only economic consequences but also important political ones. Finally, in 2011 there was none of the geopolitical tensions that erupted three years later. In short, realizing that strategy without considering the realities of the present would be very dangerous.

Two other risks of economic policy are connected with understanding of strategies' limited role.

First, indicators cannot be fetishized. The fetishization of indicators and plans at the mature stage of the Soviet economic system was the key factor of its downfall. Indicators are always imprecise reflections of real socioeconomic processes. They are always subject to manipulation. Keeping up with development trends is far more important than achieving particular formal indicators.

Secondly, short-term and long-term strategic goals (and criteria) of socioeconomic development are often in conflict. Measures that yield short-term effects tend to be harmful for mid- and long-term goals, including long-term economic growth. Additionally, it is virtually impossible to determine what ensures long-term success in the immediate future (which, in terms of political logic, means the nearest election cycle). That contradiction contains a political trap, escaping which requires no small amount of bravery and political responsibility.

Populism has become a serious problem in the world once more. One of its characteristics is the predominance of short-term interests over strategic ones. As in the twentieth century, countries at the mid-level of development are especially at risk of economic (budgetary) populism that could undermine organic

${ }^{20}$ For example, see Drobyshevsky and Sinelnikov-Murylev (2018). 
economic development. Artificial acceleration, i.e. increasing nominal growth rates at the cost of its quality and people's well-being, is one of the forms of populism that led to the collapse of the Soviet Union. Therefore, programs for economic development must be designed to achieve real, high-quality results in the mid-term perspective, rather than attractive reporting in the immediate future.

The contemporary world does not have leading sectors, but there are leading technologies that can be present in any sector. Therefore, sector priorities cannot be set in a centralized fashion. The state should ensure favorable conditions for private interest to identify and execute priority plans using the latest technologies. The key task of the state in this situation is to provide social (human capital) and transport infrastructure.

Maintaining high-quality human capital is a strategic problem. In conditions of a decreasing working-age population and a significant easing of global migration for the educated part of the population, the challenge of maintaining human capital becomes particularly difficult. There is a serious risk of a negative migration balance, i.e. the departure from the country of the most educated and sophisticated people who have a quality demand for goods and services and the arrival of the less educated poor. This puts increased requirements on the quality of state policy, since states begin to compete not only for investments, but also for quality demand in the sectors of education and healthcare. These sectors are exclusively important for solving long-term goals of growth, but their effective development requires focusing not only on their supply, but also on their demand.

And finally, a separate challenge is increasing the appeal of entrepreneurship. In Russian conditions, this is particularly important and particularly difficult, since less than thirty years ago, entrepreneurship was a crime punishable by law. Its legalization did not make private business more appealing, even in the eyes of the youth. Overcoming this aversion is one of the strategic challenges facing the country.

From the above list, it is not difficult to see that the key problems of ensuring socioeconomic performance lie in the non-economic area. They are exactly what will be the priorities of the post-crisis stage of Russia's development.

\section{References}

Caballero, R., \& Hammour, M. (1996). On the timing and efficiency of creative destruction. Quarterly Journal of Economics, 111 (3), 805-852. https://doi.org/10.2307/2946673

Drobyshevsky, S., \& Sinelnikov-Murylev, S. (2018). Peculiarities of Russia's economy growth in 2017 and 2018: Stimuli and limitations. Monitoring of Russia's economic outlook: Trends and challenges of social and economic development, 2 (63), 7-11 (in Russian).

Frankel, J. (2012). Internationalization of the RMB and historical precedents. Journal of Economic Integration, 27 (3), 329-365. https://doi.org/10.11130/jei.2012.27.3.329

Idrisov, G., Ponomarev, Y., \& Sinelnikov-Murylev, S. (2015). Terms of trade and economic development of contemporary Russia. Ekonomicheskaia Politika, 3, 7-37 (in Russian).

Idrisov, G., Mau, V., \& Bozhechkova, A. (2017). Searching for a new growth model. Voprosy Ekonomiki, 12, 5-23 (in Russian).

IMF (2017). Fintech and financial services: Initial considerations. IMF Staff Discussion Notes, No. $17 / 05$.

Kadochnikov, P., Knobel, A., \& Sinelnikov-Murylev, S. (2016). Openness of the Russian economy as a source of economic growth. Voprosy Ekonomiki, 12, 26-42 (in Russian). 
Mau V. (2014). Waiting for a new model of growth: Russia's social and economic development in 2013. Voprosy Ekonomiki, 2, 4-32.

Mau, V. A. (2016). Crises and lessons. Russian economy in a turbulent epoch. Moscow: Gaidar Institute Publ. (in Russian).

Mau, V. A., \& Kuzminov, Y. I. (Eds.) (2013). Strategy-2020: A new growth model, a new social policy. In 2 vols. Moscow: Delo (in Russian).

Murphy, M., \& Yuan, W. J. (2009). Is China ready to challenge the dollar. Internationalization of the renminbi and its implications for the United States. Washington, DC: CSIS Press.

Prasad, E. S. (2016). Gaining currency: The rise of the renminbi. New York: Oxford University Press. https://doi.org/10.1093/acprof:oso/9780190631055.001.0001

RANEPA, \& Gaidar Insititute (2017). Monitoring of Russia's economic outlook: Trends and challenges of social and economic development, No. 23 (in Russian).

Roach, S. S. (2017). Complacency will be tested in 2018. Project Syndicate, Dec. 14. URL: https:// www.project-syndicate.org/commentary/test-for-economic-complacency-in-2018-by-stephens--roach-2017-12?barrier=accesspaylog

Rodrik, D. (2017). Too late to compensate free trade's losers. Project Syndicate, Apr. 11. URL: https://www.project-syndicate.org/commentary/free-trade-losers-compensation-too-late-bydani-rodrik-2017-04?barrier=accessreg

Rodrik, D. (2018). In defence of economic populism. Project Syndicate, Jan. 9. URL: https://www. project-syndicate.org/commentary/defense-of-economic-populism-by-dani-rodrik-2018-01

Roubini, N. (2017). The mystery of missing inflation. Project Syndicate, Sept. 13. URL: https:// www.project-syndicate.org/commentary/monetary-policy-missing-inflation-by-nourielroubini-2017-09?barrier=accessreg

Schumpeter, J. (1942). Capitalism, socialism, and democracy. New York: Harper \& Bros.

Sinelnikov-Murylev, S., Drobyshevsky, S., \& Kazakova, M. Decomposition of Russian GDP growth rates in 1999-2014. Ekonomicheskaia Politika, 5, 7-37 (in Russian).

Stinchcombe, K. (2017). Ten years in, nobody has come up with a use of blockchain. Hacker Noon, Dec. 22. URL: https://hackernoon.com/ten-years-in-nobody-has-come-up-with-a-use-case-forblockchain-ee98c180100

World Inequality Lab (2018). World inequality report 2018. URL: http://wir2018.wid.world/files/ download/wir2018-full-report-english.pdf 